\title{
Transformational Leadership, Work Engagement and Performance Among Public Service Employees in Uganda
}

\author{
Victoria Nzarubara Patricia ${ }^{1 *} \quad$ Leonsio Matagi $^{2} \quad$ Simon Nantamu ${ }^{2}$ \\ 1.Makerere University, P. O. Box 7062, Kampala, Uganda \\ 2.Makerere University, School of Psychology, P. O. Box 7062, Kampala, Uganda
}

\begin{abstract}
This study aims at examining the relationship between transformational leadership, work engagement and performance among employees of the public service in Uganda. The study also reports an investigation into the mediating effect of work engagement on the relationship between transformational leadership and performance. To test the relationships between transformational leadership, work engagement and performance, the author applied the Pearson's product moment correlation coefficient. The mediating effect was tested using the three step regression analysis proposed by Baron and Kenny (1986). Data was collected from 132 employees of Ministry of Gender, Labor and Social Development in Uganda. The results show a positive and significant relationship between transformational leadership, work engagement and employee performance. Though, the inspirational motivation component of transformational leadership is not related to overall work engagement. And the transformational leadership component of individualised consideration is not related to overall performance. Work engagement is found to fully mediate the relationship between transformational leadership and employees' performance. So even when the results of this study to a certain extent are explained by the social exchange theory, emphasis should be on creating an environment of work engagement by management because this has shown to increase employee performance. However, a possible limitation could be arising from the use of self-report questionnaires. That is, responses generated from the "employees only" could have been biased because they might have expected chastisement for negative responses.
\end{abstract}

Keywords Transformational leadership, Work engagement, Performance

DOI: $10.7176 / \mathrm{EJBM} / 12-23-03$

Publication date:August $31^{\text {st }} 2020$

\section{Introduction}

Leadership is a critical component of good public governance (OECD, 2001). For this reason, leaders in public service have a major impact on the development of employee effectiveness; making leadership an essential element for organizations today (Schein, 2010). Bass (1990) suggests that leadership is characterized by an interactive process between a leader and their followers.

The interactive process can be found in transformational leadership which this study focuses on. Transformational leadership has been described as a set of behaviors that motivate followers to achieve performance beyond basic expectations (Bass, 1985). Work engagement as an effect of transformational leadership can be described by the conditions under which people work (Wright \& Cropanzano, 2000). Employee performance then implies an individual's success after exerting effort on the job gotten through meaningful work and considerate colleagues as well as leaders around (Karakas, 2010).

In effect, studies have shown that transformational leadership, work engagement and performance are indeed related. For instance, Ghadi, Fernando and Caputi, (2013) states that transformational leadership influences the subordinates' perception of meaning of work leading to higher work engagement. While Bakker and Schaufeli (2008) reveal that work engagement enhances performance because engaged employees exhibit a wide range of productive behaviors that enhance combined efforts toward achieving organisational goals which may lead to enhanced individual employee performance. On the other hand, transformational leadership inspires followers to go beyond their own self-interest to achieve high levels of performance (George \& Jones, 2012).

These relationships can be understood based on the social exchange theory and the norm of reciprocity (Homan, 1958; Blau, 1964). When leaders use less authority and instead act as guides, mentors and coaches in order to enhance the vision of the followers, the employees may reciprocate through enhanced performance to enable the organisation meet its goals (Geyer \& Steyrer, 1998).

However, according to Vajda and SpiritHeart (2008), disengaged employees vastly cause their businesses harm because they lack interpersonal relations in dealing with the customer contentment and this becomes a great loss to organizations. In Uganda, a survey carried out by the Federation of Ugandan Employers (FUE) to investigate the initiatives that organizations had in place to optimize engagement discovered that it was poorly perceived and handled (Kikooma, Nansubuga \& Research Team, 2017). It's no wonder that the public service is still criticized for being slow, corrupt, inaccessible, rigid, and unresponsive to the needs of the people translating into low performance (Basheka, 2014). It lacks leaders that are able to model the way, challenge the status-quo and encourage the hearts of their subordinates to perform to their greatest potential; yet providing transformational 
leadership, ethics and to model good conduct is among the key duties of public officials in Uganda (Ministry of Public Service, 2011). Therefore, appropriate styles of leadership should be used in order for employees to perform effectively; and these should be styles that enhance an environment of work engagement within the organisation.

\section{Theoretical background and hypothesis development}

\subsection{Transformational Leadership and Work Engagement}

Studies have shown that transformational leaders influence their subordinates' perception of meaning of work, leading to higher engagement (Thisera \& Sewwandi, 2018).

Gyensare, Kumedzro, Sanda and Boso, (2017) investigated the relationship between transformational leadership and work engagement in a large public sector organisation in Ghana. The sample consisted of 336 employees and the results showed a positive and significant relationship between transformational leadership and work engagement. Their study suggested that supervisors in the African public sector should improve their mutual relationships with their followers as can be seen in the core concept of the Social Exchange Theory.

Datche and Mukulu (2015) examined the relationship between transformational leadership and work engagement in the civil service of Kenya. Data was taken from 252 civil servants from 18 top performing state corporations using a stratified random sampling technique. The results showed that transformational leadership was positively related to engagement; however, the inspirational motivation dimension of transformational leadership was insignificant while idealised influence dimension was negatively related to employee engagement. It was proposed that training programs about transformational leadership should be developed for supervisors in civil service with emphasis on inspirational motivation and idealised influence in order to enhance the engagement levels of their subordinates in the organizations.

Thisera and Sewwandi (2018) examined the influence of transformational leadership on work engagement in the hospitality sector in Sri Lanka. Data which was collected through self-administered questionnaires from 245 executive level employees found that transformational leadership positively influenced the employee engagement in the hospitality industry. The findings recommended that organisations can enhance the engagement of their employees by developing transformational leaders.

Lacap (2019) also looked the association between transformational leadership and engagement among teaching and non-teaching staff some local colleges in Philippines. The study revealed that transformational leadership significantly affects employees' engagement levels which mean that employee engagement rises when workers experience transformational leadership in the organisation.

In addition, Al-Amin (2017) found a positive and significant relationship between transformational leadership and work engagement among 200 employees working in a variety of jobs in Small Medium Enterprises (SMEs) of Bangladesh. The study therefore suggested that when leaders' behaviors are supportive of followers' development, then the employees will express a higher level of engagement.

Similarly, Bui, Zeng, and Higgs (2017) found a positive relationship among 691 full time employees in China using structure equation modeling with maximum likelihood estimation on Mplus with bootstrapping proposed by Hayes (2009). They emphasised the fact that people have less control over their own engagement than they think as their engagement can be influenced by other external factors like the characteristics of their leaders.

At team-level, Aw and Ayoko (2017) found that transformational leadership is positively related to team work engagement. The sample consisted of 261 employees randomly recruited from 41 also randomly selected teams in Multinational Corporation in Singapore. This provides support for the argument that a transformational leader is important for effective team work engagement (Breevaart et al., 2015).Therefore, in the study it was suggested that organizations should consider training leaders in transformational leadership behaviors at the team and organisational levels in order to enhance the levels of team work engagement.

Ghadi et al. (2013) examined the relationship between transformational leadership and work engagement among a sample of 530 full-time employees working in Australia. The results showed that there was a positive and significant relationship between transformational leadership and work engagement. They therefore proposed that human resource (HR) managers who aim at generating levels of engagement in the long term should offer new programmes that improve transformational leadership behaviors among the Supervisors in the organization.

In the service sector firms of Pakistan, Raja (2012) found a positive and significant relationship between transformational leadership and work engagement. It was presumed that when all aspects of transformational leadership, that is, idealised influence, inspirational motivation, intellectual stimulation, and individual consideration are expressed together; the employees' work engagement tends to be higher.

However, Sandell (2012), found that the relationship between transformational leadership and work engagement was not significant. The study indicated that one's level of engagement can be influenced by the extent to which one perceives his or her leader to exhibit the transformational style. This shows that the leader shapes the employee's environment through specific interactions, rather than through dramatic, sweeping gestures meant to fit under a particular leadership style (Larsson \& Lundholm, 2010).

Also, Hamman (2012) found an insignificant relationship between transformational leadership and work 
engagement in a National Human Resource consulting firm in South Africa. A few leaders participated in the study $(n=21)$; it's probable that a larger number of leaders could have led the study to generate different results. Also, the study suggested that management might have required the employees to deliver on a particular activity and therefore used other leadership behaviors in order to get the job done such as contingent rewards.

The studies have shown that there is a positive influence of transformational leadership on employee engagement, however, similar empirical studies in the public service of Uganda are lacking. This study therefore proposes the following hypothesis:

H1: Transformational leadership is positively related to work engagement among employees of the public service of Uganda.

\subsection{Work Engagement and Employee Performance}

Amoako-Asiedu and Obuobisa-Darko (2017) investigated the relationship between work engagement and employee performance within the public sector organisations in Ghana and found that engaged employees put in their best to ensure performance. The sample consisted of MPA and PhD students from the Universities of Ghana (UG), University of Professional Studies (UPS) and students of the Ghana Institute of Management and Public Administration (GIMPA) who were working in the public service. The study focused on these students/practitioners because they understood the importance of research and within the university settings they were away from the hustle of the work environment which might have influenced the accuracy of their responses. The study disclosed that when employees found fairness, flexibility, involvement in decision making and an environment where they felt valued and respected, then this would make them engaged. And these engaged employees would put in their best to ensure enhanced levels of performance.

Sanneh (2015) also found a positive and significant relationship between work engagement and employee performance in the Gambia Ports Authority. The sample consisted of 327 respondents who included employees at different levels within the organisation such as senior managers, directors, and junior level staff. The study therefore concluded that organisations should bring together employees when making decisions and strategic plans because such experiences arouse efficiency and productivity in the Organisation.

Similarly, Sendawula, Kimuli, Bananuka and Muganga, (2018) contended that work engagement had a positive and significant relationship with employee performance in their study carried out in the health sector of Uganda with a sample of 150 respondents from four Catholic founded hospitals. It was recommended that supervisors should involve employees in developing policies, procedures and decision making because this compels them to fulfill organisational goals with dedication hence enhanced performance.

In a study carried out among customer service employees in a large state-owned telecom company in South China, results showed that work engagement has a positive relationship with task performance. This implied that an engaged workforce is more likely to perform their tasks more efficiently and effectively (Du, Xie \& Mo, 2017).

Memon, Soomro and Kumar (2018) also reported a positive relationship between work engagement and employee performance in their study carried out among 150 employees of different hierarchical positions in different banks. Their recommendation was that top management in banks should do everything possible to ensure that their employees are engaged such as showing concerns about their needs, ensuring that each employee is aware about her/his job duties, amongst others.

Soares, Veloso, Ferreira-Oliveira, and Silva (2017) examined the relationship between work engagement and employee performance with emphasis on whether the engagement of the employees varied during a working day. The study which was carried out in a state owned hospital in Portugal with 23 employees answering the feedback form twice a day found that work engagement had a positive relationship with performance. However, they also found that the absorption levels had faded during the day perhaps due to a busy working day. This showed that it is possible for work engagement to change during the course of the day and can also shine a light on the time when employees are most fruitful while at work.

Al-Amin (2017) confirmed a positive and significant relationship between work engagement and employee performance among 200 employees working in a variety of jobs in Small Medium Enterprises (SMEs) of Bangladesh. The practical implications suggested that highly engaged employees have better levels of positive performance.

According to Bakker, Demerouti and ten Brummelhuishas (2012a), work engagement was positively associated with employee performance. These results were obtained by using supervisor's rating of task performance and contextual performance. However, the study also revealed that though work engagement is necessary, other factors such as the personality traits of the employees can lead to increased productivity.

In addition, Pham-thai, McMurray, Muenjohn and Muchiri (2018) carried out a study to examine the relationships between engagement, transformational leadership, high-performance human resource (HR) practices, climate for innovation, and contextual performance among Vietnamese university academics and their leaders. The study showed that engagement contributed significantly and positively to enhance contextual performance. This is in agreement with Kahn (1990) which highlights engaged employees as those fully investing in their 
physical, cognitive, and emotional energies in their job performance.

Studies demonstrating a relationship between work engagement and performance among employees in the public service of Uganda are lacking and therefore, this study proposes the following the hypothesis:

H2: Work engagement is positively related to performance among employees of the public service of Uganda.

\subsection{Transformational Leadership and Employee Performance}

Choon, Ibrahim, Kowang, and Fei (2018) carried out a study in the public sector of Malaysia where they found that transformational leadership was positively and significantly related to employee performance. The results supported the notion that transformational leaders are able to assign tasks to the employees in accordance with their capabilities. This in return allows employees to experience success and gain more self-confidence in achieving excellent performance (Conger \& Kanungo, 1987).

Alfanda and Suhartanti (2018) also found a positive and significant relationship between transformational leadership and women leaders' performance in a study carried out among Universities in the Aceh region. The study therefore recommended that in order for performance of women to improve especially in the Education sector, the Government of Aceh would have to improve on transformational leadership.

Similarly, Manzoor et al., (2019) reported a positive relationship in their study examining the impact of transformational leadership on performance among employees working in the Small and Medium Enterprises (SMEs) of Pakistan. It was recommended that top-level management should receive training in transformational leadership, which will boost the performance of their employees as well as the overall organizational performance.

Ribeiro, Yucel and Gomes, (2018) examined the impact of transformational leadership on employee performance among 476 Turkish healthcare professionals and found a direct and non-significant relationship. The findings further indicated that transformational leaders enhance employees' expectations and recognition of their work and increase employees' performance through behaviors such as individual attention, inspiration, intellectual stimulation and motivation. This relationship can be understood as a reciprocal exchange based on the Social Exchange Theory (Blau, 1964). The exchanges are characterized by reciprocity whereby when one associate provides a benefit to another, the act produces a sense of obligation on the part of the latter to reciprocate at a later point (Ribeiro et al., 2018).

Nazarian, Soares, and Lottermoser (2017) also found that there was a positive significant relationship between transformational leadership and performance. The study aimed at investigating how leadership is perceived in organisations and its influence on the performance of young professionals (Generation Y). Their findings implied that leaders who adopt the transformational leadership style have the potential of achieving both individual and organisational objectives to a greater extent than leaders that choose a different style of leadership.

In another related study, the relationship between transformational leadership and contextual performance was shown to be positive among Indian IT professionals (Pradhan, Jena, \& Bhattacharyya, 2018). This is in agreement with some studies that found that leaders who communicate a compelling image of where they want the employees and Organisation to be in the future usually have enhanced contextual performance (Bass, 1985).

Para-gonzález, Jiménez-jiménez, and Martínez-lorente (2018) in their study to determine the mediating mechanisms of Human Resource Management (HRM), learning and innovation that could exist in the relationship between transformational leadership and performance, found that transformational leadership improves performance when specific systems of HRM practices, learning and innovation are developed in an organization. The research explored the relationships using Partial Least Squares with data from 200 Spanish industrial companies. Their study, therefore, contributed to the understanding of the link between transformational leaders and performance by proposing a model in which this leadership style produces synergies between HRM, learning and innovation, hence affecting performance.

Similarly, Bacha (2014) found that when the leader was male, there was a partial relationship between transformational leadership and follower task performance, however, when the leader was female, there was no relationship between transformational leadership and task performance. But the study could not generalise the findings because the sample consisted of 28 females and 72 male leaders who were from different sectors in both private and public French firms (Bacha, 2014).

There is hardly any study showing a relationship between transformational leadership and employee performance in the public service of Uganda. This study therefore proposes the following hypothesis:

H3: Transformational leadership is positively related to performance among employees of the public service of Uganda.

\subsection{Work engagement as a mediator between transformational leadership and employee performance}

Shokory and Suradi (2018) carried out a study on the mediating role of work engagement as the relevant variable which affects the degree of influence that transformational leadership has on employees' contextual (extra-role) performance. The findings revealed that the work engagement of the project team members $(n=195)$ from 
different contractors in Selangor significantly mediated the relationship between transformational leadership of the project manager and conceptual performance (extra-role) of the project team members.

Results from another study carried out among nurses in a large Portuguese hospital whose extra-role performance was assessed by their supervisors showed that self efficacy partially mediated the relationship between transformational leadership and employee performance at variance of $12 \%$ while work engagement fully mediated the relationship between transformational leadership and employee performance at a variance of $19 \%$ (Salanova, Lorente, Chambel, \& Martınez, 2011).

However, in the Kenyan public service, work engagement was found to partially mediate the relationship between transformational leadership and employee performance (Datche \& Gachunga, 2015). The study was conducted among 252 civil servants from 18 top performing State Corporations in Kenya based on the $2010 / 2011$ performance. The study recommended that HR departments within organisations should develop strategies and training programs around transformational leadership skills such as being supportive and providing a vision to employees if they are to influence both their employees' engagement levels and thus performance.

Also Abas, Sawitri, and Puspawati (2018) reported that work engagement partially mediated the effect of transformational leadership on performance. The study was carried out among 97 employees of a pharmaceutical company in Indonesia especially Solo Raya and Madiun City. This implied that when transformational leadership is present, the employees are more engaged to their work, which in turn promotes performance.

There is hardly any study investigating the mediational role of work engagement between transformational leadership and employee performance particularly in the public service of Uganda, therefore, this study proposes the following hypothesis:

H4: Work engagement significantly mediates the relationship between transformational leadership and performance among employees of the public service of Uganda.

\section{Figure I: Conceptual Framework}

This conceptual framework below describes the relationships between transformational leadership, work engagement and employee performance

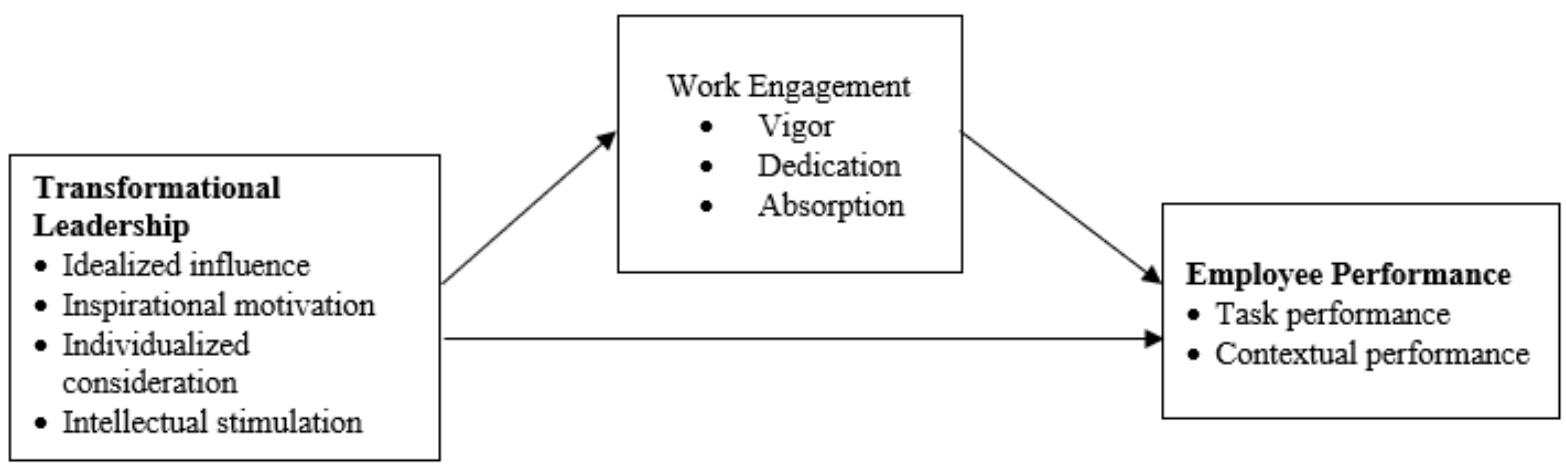

Figure 1: The conceptual framework

\section{Methodology}

\subsection{Sample and procedures}

A sample of 132 employees working with the Ministry of Gender, Labor and Social Development which number was arrived at using the statistical table for determining sample size (Krejcie \& Morgan, 1970). The sample was selected by convenience sampling technique in order for respondents to participate in the study at their convenience and availability (Etikan, Musa, \& Alkassim, 2016).

An introductory letter of the study to the Ministry of Gender, Labor and Social Development was obtained from the School of Psychology, Makerere University. The letter was taken to the Head of Human Resource (HR) and explained the relevance of the study in enhancing the employees' performance. With approval granted, the researcher then approached the selected employees, explained the purpose of the study and how it would benefit them. Thereafter, the researcher handed out the questionnaires and guided them on how to fill them. Some respondents answered the questionnaires immediately and handed them back to the researcher while others were collected after a couple of days. In total, 132 questionnaires were received.

Within the sample, majority of the respondents were male at $53.9 \%$ between the age ranges of $25-35$ at $60.8 \%$ and were married at 55.7\% having worked in the Ministry for a year at $28.9 \%$ with the highest qualification attained being a bachelor's degree at $38.6 \%$. While the least respondents were female at $46.1 \%$ above the age of 55 years at $2.3 \%$ and were divorced at $.8 \%$. The least work tenure was between $12-30$ years at $.8 \%$ with the highest qualification attained being a Post Graduate Diploma (PGD) at $2.3 \%$.

For gender, "Male" was coded as 1, "Female" coded as 2 ; For age, "less than 25 " coded as 1, " 25 - 35 " coded as 2, "36-45" coded as 3, "46 -55" coded as 4, "55 and above" coded as 5; For marital status, "Married" coded as 
1, "Not married" coded as 2, "Divorced" coded as 3 and "Widowed" coded as 4; For employment period "Less than 1 year" coded as 1 , " $1-5$ years" coded as 2, " $6-10$ years" coded as 3 and " 11 years and above" coded as 4 .

\subsection{Measures}

A questionnaire with closed ended questions was used to collect data from the selected respondents. It included the Multi factor Leadership questionnaire (MLQ) for measuring transformational leadership, the 17-item Utrecht Work engagement scale (UWES) for measuring work engagement and the Individual Work Performance Questionnaire (IWPQ) for measuring employee performance.

Transformational leadership was measured using the 20-item Multifactor Leadership Questionnaire (MLQ). This instrument was developed by Bass and Avolio (2000) and has been used by researchers (Choon et al., 2018; Pradhan et al., 2018; Ribeiro et al., 2018) with an internal consistency of at least 0.95 . It has a five point Likert scale ranging from scale of "strongly disagree" coded as 1 , "disagree" coded as 2 , "neither disagree nor agree" coded as 3; "agree" coded as 4; "strongly agree" coded as 5.

The Utrecht Work Engagement Scale (UWES) was developed to measure three related factors of work engagement: vigor, dedication and absorption (Schaufeli, Salanova, Gonzalez-Roma \& Bakker, 2002). It's a 17item questionnaire with a 5-point scale measuring "strongly disagree" coded as 1; "disagree" coded as 2; "neither disagree nor agree" coded as 3 , "agree" coded as 4, "strongly agree" coded as 5 . The subscales include; vigor (for example, when I get up in the morning, I feel like going to work.), dedication (I am enthusiastic about my job) and absorption (for example, When am working, I forget everything else around me.). It has been used in different studies (Schaufeli, 2013; Ashforth \& Humphrey, 1995; Ubaid et al., 2017; Xu and Cooper-Thomas, 2011) with an internal consistency of at least 0.90 .

Individual Work Performance Questionnaire (IWPQ) version 1.0 was developed by Koopmans et al., 2014. The task performance scale consists of 7 items (for example, I managed to plan my work so that it was done in time) with an internal consistency of 0.81 . The contextual performance scale consists of 6 items (for example, I started new tasks when my old tasks were finished) with an internal consistency of 0.85 . The IWPQ version 1.0 measures using a 5-item Likert scale ranging from "never" coded as 1; "rarely" coded as 2; "sometimes" coded as 3; "frequently" coded as 4; and "Always" coded as 5. The self report questionnaire has been used widely and validated by several research work, for example, Chugtai \& Buckley, 2011; Lee, Tan, \& Javalgi, 2010; Leung, Chan, \& Dongyu, 2011; Biswas \& Varma, 2011; Ribeiro et al., 2018; Robertson, Birch, \& Cooper, 2012; Jackson, 2014; Ming, 2015; Reina-tamayo, Bakker, \& Derks, 2018; Lisbona, Palaci, Salanova, \& Frese, 2018; Pradhan \& Jena, 2017.

\subsection{Quality control}

Validity of the results were ensured by adopting standardised scales during the research and employing the expert opinion of my supervisors who helped in clarifying the instructions and wordings of the items amongst others. For instance, initially in Section D of the questionnaire, the responses were coded as $1=$ Seldom, $2=$ Sometimes, $3=$ Frequently, $4=$ Often and $5=$ Always. However, this was changed to $1=$ Never, $2=$ Rarely, $3=$ Sometimes, $4=$ Frequently and $5=$ Always for easier interpretation by the respondents.

Reliability was ensured by using reliability analysis in order to ascertain which items had at least a reliability coefficient of .70. Those items with a Cronbach alpha of above .70 were retained. In psychometric testing, tests must fall within the range of .70 and above in order for them to be considered reliable (Nunnally, 1978).

\subsection{Analysis}

Data was entered into Statistical Package for Social Sciences (SPSS) version 21. Pearson's Product Moment Correlation Coefficient (Pearson's $r$ ) was used to test the first three hypotheses. Hypothesis four was tested using Baron and Kenny (1986)'s three step/equation regression analysis. In this case, first, work engagement (the mediating variable) was regressed on transformational leadership (the independent variable); secondly, employee performance (the dependent variable) was regressed on transformational leadership and thirdly, employee performance was simultaneously regressed on transformational leadership and work engagement.

According to Baron and Kenny (1986), in order for mediation to take place, the following conditions must be maintained; that is, the independent variable must affect the mediator in the first equation; then the independent variable must be shown to affect the dependent variable in the second equation and lastly, the mediator must affect the dependent variable in the third equation. If these conditions all hold in the predicted direction, then the effect of transformational leadership on employee performance must be less in the third equation than in the second equation. Perfect mediation holds if transformational leadership has no effect when work engagement is controlled. However, partial mediation holds if transformational leadership's effect is reduced in magnitude, but is still significant when work engagement is controlled. 


\section{Results}

4.1 Transformational leadership and work engagement

Statistical results in table one show that overall transformational leadership was found to be positively and significantly related to overall work engagement $(\mathrm{r}=.24, \mathrm{p}<0.05)$. There was a positive and significant relationship between overall transformational leadership and the work engagement component of vigor $(\mathrm{r}=.22, \mathrm{p}$ $<0.05)$ and dedication $(\mathrm{r}=.28, \mathrm{p}<0.01)$ however, there was no significant relationship between overall transformational leadership and the work engagement component of absorption.

The inspirational motivation component of transformational leadership was not related to overall work engagement $(\mathrm{r}=. .06, \mathrm{p}>0.05)$, unlike the other three components of intellectual stimulation $(\mathrm{r}=.27, \mathrm{p}<0.01)$, idealized influence $(\mathrm{r}=.24, \mathrm{p}<0.05)$ and individualized consideration $(\mathrm{r}=.22, \mathrm{p}<0.05)$.

Table I: Pearson's correlation results of transformational leadership and work engagement

\begin{tabular}{|c|c|c|c|c|c|c|c|c|c|}
\hline Variables & 1 & 2 & 3 & 4 & 5 & 6 & 7 & 8 & 9 \\
\hline 1. Intellectual stimulation & 1 & & & & & & & & \\
\hline 2. Idealized influence & $.72 * *$ & 1 & & & & & & & \\
\hline 3. Individualized consideration & $.43 * *$ & $.61 * *$ & 1 & & & & & & \\
\hline 4. Inspirational motivation & $.51 * *$ & $.59 * *$ & $.35 * *$ & 1 & & & & & \\
\hline 5. Vigor & $.21^{*}$ & $.25^{*}$ & $.26 * *$ & .06 & 1 & & & & \\
\hline 6. Dedication & $.19 *$ & $.25 * *$ & .11 & .14 & $.65 * *$ & 1 & & & \\
\hline 7. Absorption & $.28 * *$ & .18 & .17 & .06 & $.58 * *$ & $.46^{* *}$ & 1 & & \\
\hline 8. Overall work engagement & $.27 * *$ & $.24^{*}$ & $.22 *$ & .06 & $.89 * *$ & $.82 * *$ & $.84 * *$ & 1 & \\
\hline 9. Overall transformational leadership & $.85 * *$ & $.94 * *$ & $.72 * *$ & $.77 * *$ & $.22 *$ & $.28 * *$ & .19 & $.24 *$ & 1 \\
\hline
\end{tabular}

* correlation is significant at the 0.05 level 2-tailed; ** correlation is significant at the 0.01 level 2-tailed

4.2 Work engagement and employee performance

Statistical results in table two show that overall work engagement was found to be positively and significantly related to overall employee performance $(r=.39, \mathrm{p}<0.01)$. Also, there was a positive and significant relationship between overall work engagement and the components of performance, that is, task performance $(r=.33, p<0.01)$ and contextual performance $(\mathrm{r}=.37, \mathrm{p}<0.01)$.

Employee performance was positively and significantly related to the work engagement components of vigor $(\mathrm{r}=.37, \mathrm{p}<0.01)$, dedication $(\mathrm{r}=.29, \mathrm{p}<0.01)$ and absorption $(\mathrm{r}=.23, \mathrm{p}<0.05)$.

Table II: Pearson's correlation results of work engagement and employee performance

\begin{tabular}{|c|c|c|c|c|c|c|c|}
\hline Variables & 1 & 2 & 3 & 4 & 5 & 6 & 7 \\
\hline 1. Vigor & 1 & & & & & & \\
\hline 2. Dedication & $.65 * *$ & 1 & & & & & \\
\hline 3. Absorption & $.58 * *$ & $.46^{* *}$ & 1 & & & & \\
\hline 4. Task performance & $.32 * *$ & $.28 * *$ & $.22 *$ & 1 & & & \\
\hline 5. Contextual performance & $.35 * *$ & $.27 * *$ & $.24 *$ & $.56 * *$ & 1 & & \\
\hline 6. Overall work engagement & $.89 * *$ & $.82 * *$ & $.84 * *$ & $.33 * *$ & $.37 * *$ & 1 & \\
\hline 7. Overall employee performance & $.37 * *$ & $.29 * *$ & $.23 *$ & $.79 * *$ & $.95 * *$ & $.39 * *$ & 1 \\
\hline
\end{tabular}

* correlation is significant at the 0.05 level 2- tailed; ** correlation is significant at the 0.01 level 2-tailed

\subsection{Transformational leadership and employee performance}

Statistical results in table three show that overall transformational leadership was found to be positively and significantly related to overall employee performance $(\mathrm{r}=.26, \mathrm{p}<0.05)$. Also, there was a positive and significant relationship between overall transformational leadership and the components of employee performance, that is, task performance $(r=.29, \mathrm{p}<0.01)$ and contextual performance $(r=.27, p<0.05)$.

However, unlike the transformational leadership component of individualized consideration which is not significantly related to overall performance $(\mathrm{r}=.13, \mathrm{p}>0.05)$, the other three components of inspirational motivation $(r=.25, \mathrm{p}<0.05)$, idealized influence $(\mathrm{r}=.21, \mathrm{p}<0.05)$ and intellectual stimulation $(\mathrm{r}=.24, \mathrm{p}<0.05)$ are significantly and positively related to overall employee performance. 
Table III: Pearson's correlation results of transformational leadership and employee performance

\begin{tabular}{|c|c|c|c|c|c|c|c|c|}
\hline Variable & 1 & 2 & 3 & 4 & 5 & 6 & 7 & 8 \\
\hline 1. Intellectual stimulation & 1 & & & & & & & \\
\hline 2. Idealized influence & $.72 * *$ & 1 & & & & & & \\
\hline 3. Individualized consideration & $.43 * *$ & $.61 * *$ & 1 & & & & & \\
\hline 4. Inspirational motivation & $.51 * *$ & $.59 * *$ & $.35 * *$ & 1 & & & & \\
\hline 5. Task performance & $.32 * *$ & $.26 * *$ & .07 & $.28 * *$ & 1 & & & \\
\hline 6. Contextual performance & .19 & $.21 *$ & $.19 *$ & $.22 *$ & $.56^{* *}$ & 1 & & \\
\hline 7. Overall transformational leadership & $.85^{* *}$ & $.94 * *$ & $.72 * *$ & $.77 * *$ & $.29 * *$ & $.27 *$ & 1 & \\
\hline 8. Overall employee performance & $.24 *$ & $.21 *$ & .13 & $.25 *$ & $.79 * *$ & $.95^{* *}$ & $.26^{*}$ & 1 \\
\hline
\end{tabular}

* correlation is significant at the 0.05 level 2-tailed; ** correlation is significant at the 0.01 level 2-tailed

\subsection{Mediating effect of work engagement}

Statistical results in table four show that transformational leadership significantly predicts work engagement in the first equation $(t=2.24, p<0.05)$. Secondly, transformational leadership significantly predicts employee performance in the second equation $(t=2.46, p<0.05)$. And in the third equation, work engagement is the only significant predictor of employee performance $(t=3.11, p<0.01)$ indicating perfect mediation. Perfect mediation holds because transformational leadership does not significantly predict performance when work engagement is controlled. Therefore, work engagement fully mediates the relationship between transformational leadership and employee performance.

Table IV: Mediation results

\begin{tabular}{|c|c|c|c|c|c|c|c|c|}
\hline Equation & $\begin{array}{c}\text { Dependent } \\
\text { variable }\end{array}$ & $\begin{array}{c}\text { Independent } \\
\text { variable }\end{array}$ & Beta & $\begin{array}{c}t- \\
\text { value }\end{array}$ & $\begin{array}{c}\text { Sig. of } \\
t\end{array}$ & $\begin{array}{c}F \\
\text { value }\end{array}$ & $\begin{array}{l}\text { Sig. of } \\
\text { F }\end{array}$ & $\begin{array}{l}\text { Adjusted } \\
\text { R Square }\end{array}$ \\
\hline 1. & $\begin{array}{l}\text { Work } \\
\text { engagement }\end{array}$ & $\begin{array}{l}\text { Transformational } \\
\text { leadership }\end{array}$ & .24 & 2.24 & .04 & 5.01 & $0.28^{\mathrm{b}}$ & 0.46 \\
\hline 2. & $\begin{array}{l}\text { Employee } \\
\text { performance }\end{array}$ & $\begin{array}{l}\text { Transformational } \\
\text { leadership }\end{array}$ & .26 & 2.46 & .02 & 6.07 & $0.16^{\mathrm{b}}$ & 0.06 \\
\hline \multirow[t]{2}{*}{3.} & $\begin{array}{l}\text { Employee } \\
\text { performance }\end{array}$ & $\begin{array}{l}\text { Transformational } \\
\text { leadership }\end{array}$ & .20 & 1.78 & .08 & 8.42 & $.001^{\mathrm{b}}$ & .17 \\
\hline & & Work engagement & .34 & 3.11 & .00 & & & \\
\hline
\end{tabular}

\section{Discussion}

5.1 Transformational leadership and work engagement

From the study, results indicate that there is a positive and significant relationship between overall transformational leadership and overall work engagement. This implies that as leaders display transformational leadership behaviors, work engagement of the subordinates also increases which is in line with the findings of Thisera and Sewwandi (2018) and Lacap (2019). The results also show that both work engagement components of vigor and dedication are significantly related to overall transformational leadership. But the work engagement component of absorption was not related to overall transformational leadership. This could imply that some employees are very passionate about their work and therefore do not need a transformational leadership in order for them to perform. In addition, it was found that that the inspirational motivation component of transformational leadership was not related to overall work engagement. A possible reason for this could be that the transformational leadership component of inspirational motivation may not be exhibited by supervisors in the public service and that's why it is not related to work engagement. This study therefore retains the alternative hypothesis which stated that there would be a positive and significant relationship between transformational leadership and work engagement among employees of the public service of Uganda.

However, these findings are not in line with that of Hamman (2012) who reported a negative relationship between transformational leadership and work engagement. The study suggested that the lack of a correlation may have been caused by a change in management behaviors hastened by certain situational factors that the organization might have been experiencing at the time such as the need for increased performance.

\subsection{Work engagement and employee performance}

A positive and significant relationship was found between work engagement and employee performance. This implies that when employees are engrossed in their work, there will be high levels of performance in the organization. The employees will work passionately and tirelessly in order to achieve their goals leading to enhanced performance. Also, there was a positive and significant relationship between overall work engagement and the components of performance, that is, task performance and contextual performance. These results support the studies of Amoako-Asiedu and Obuobisa-Darko (2017) who revealed that engaged employees put in their best effort to ensure enhanced performance. The study therefore retains the alternative hypothesis which stated that 
there would be a positive and significant relationship between work engagement and performance among employees of the public service of Uganda.

\subsection{Transformational leadership and employee performance}

The findings showed that overall transformational leadership was found to be positively and significantly related to overall employee performance. This implies that when the components of transformational leadership are demonstrated, they create a conducive environment for increasing performance among the employees. These findings are in line with Choon et al., (2018) and Ribeiro et al., (2018) who similarly reported correlations between transformational leadership and employee performance. This study therefore retains the alternative hypothesis which stated that there would be a positive and significant relationship between transformational leadership and employee performance.

However, there was a non-significant relationship found between the transformational leadership component of individualized consideration and overall performance. This finding indicates that when any one of these components is ignored, performance of the employees may also decline.

\subsection{The mediating role of work engagement}

Results indicated that work engagement fully mediated the relationship between transformational leadership and employee performance. This implies that in order for transformational leadership to cause an impact on employee performance, it would have to go through work engagement. Therefore, work engagement becomes the vessel through which transformational leadership relates with employee performance. And therefore, the study retains the alternative hypothesis which stated that work engagement fully mediates the relationship between transformational leadership and employee performance.

The findings, however, are not in line with Datche \& Gachunga (2015) and Abas et al., (2018) who reported that work engagement partially mediated the relationship between transformational leadership and employee performance. This meant that the behaviors produced by transformational leaders engage employees at their work place enabling them to go the extra mile for the organization leading to enhanced performance.

\section{Conclusion}

In the study, overall transformational leadership has been shown to positively and significantly relate with overall work engagement. However, the inspirational motivation component of transformational leadership was not related to overall work engagement. Overall work engagement has been shown to positively and significantly relate with overall employee performance. Overall transformational leadership has been shown to positively and significantly relate with overall employee performance. However, the transformational leadership component of individualised consideration was not related to overall performance. And finally, work engagement has been shown to fully mediate the relationship between transformation leadership and employee performance.

\section{Practical implications}

Management in the public service should be trained in transformational leadership behaviors and its benefits to the employees. Also, recruitment for managerial positions should aim at bringing on board individuals who show signs/evidence of transformational leadership behaviors and skills. This is because transformational leaders encourage an environment of work engagement amongst the employees.

When employees are engaged in their work, they work tooth and nail to perfect it leading to enhanced performance. Therefore, this study recommends that techniques to foster an appropriate context where employees can develop work engagement should be utilized such as open communication, creative thinking, and employee skill development amongst others because this has shown to improve performance.

Performance appraisals especially for supervisory positions should include assessment of supervisors in transformational leadership behaviors since this is a key foundation to performance in the public service.

In addition, the study recommends that the public service should put emphasis on work engagement because it's a major approach to achieving enhanced performance among employees. This may be done through employing individuals with a passion for the job or placing incentives that enable people to develop attachment to their job responsibilities. Such incentives may include encouraging creative thinking, recognizing individuals who have excelled at their work amongst others.

\section{Limitations}

To begin with, the study used self-report questionnaires to generate responses from the employees which could have resulted into biased information. Respondents might have expected chastisement for negative responses yet self-report measures are important because they come from the very employees who experience and observe the activities in the organization.

Another possible limitation to this study was related to the sample scope used which comprised solely on the 
staff working at one Ministry out of the 25 Ministries in the Public Service of Uganda. Therefore, it is tricky to generalize these findings to the entire public service in Uganda.

\section{Areas for future research}

Future research should rate employees' perceptions of transformational leadership, work engagement and performance from both the supervisors and employees. The differing views and responses generated will reduce the likelihood of social desirability and give more credible results. Also, future studies are encouraged to include additional Ministries in the public service which would increase the sample dimension and the number of participants.

In addition, future studies in this area are encouraged to investigate why the individualised component of transformational leadership is not related to overall performance. Additionally, an investigation into the reason why the inspirational motivation component of transformational leadership was not related to overall work engagement should be considered.

\section{References}

Abas, N. I., Sawitri, H. S. R., \& Puspawati, D. (2018). Transformational Leadership, job performance, and organizational Citizenship Behavior: Mediating role of work engagement. Sriwijaya International Journal of Dynamic Economics and Business, 2(4), 363-376.

Al-Amin. (2017a). Transformational Leadership And Employee Perormance mediating Effect of Employee Engagement. North South Business Review, 7(2), 28-40.

Al-Amin, M. (2017b). Transformational leadership and employee performance: mediating effect of employee engagement. North South Business Review, 7(2), 28-40.

Alfanda,R.,\&Suhartanti,P. D.(2018).Transformational leadership and performance of University leaders in Aceh :Gender Perspective. International Journal of Social Sciences and Humanities Invention, 5(01), 4363-4369.

Amoako-Asiedu, E., \& Obuobisa-Darko, T. (2017). Leadership, employee engagement and employee performance in the Public Sector of Ghana. Journal of Business and Management Sciences, 5(2), $27-34$. https://doi.org/10.12691/jbms-5-2-1

Ashforth, B. E., \& Humphrey, R. H. (1995). Emotion in the Workplace: A Reappraisal. Human Relations, 48(2), 97-125. https://doi.org/10.1177/001872679504800201

Aw, V. K. J., \& Ayoko, O. B. (2017). The impact of followers' con flict behaviors on teams' transformational leadership, team member exchange and engagement. International Journal of Conflict Management, 28(4), 509-532. https://doi.org/10.1108/IJCMA-04-2016-0020

Bacha, E. (2014). The relationship between transformational leadership , task performance and job characteristics. Management Development, 33(4), 410-420.

Bakker, A.B. Demerouti, E., \& Ten Brummelhuis, L.L. (2012a). Work engagement, Performance and active learning: the role of conscientiousness. Journal of Vocational Behavior, 80,555-64

Bakker, A.B. \& Schaufeli, W.B. (2008). Positive organizational behavior: Engaged employees in flourishing organizations. Journal of Organizational Behavior, 29, 147-154.

Baron, R. M., \& Kenny, D. A. (1986). The Moderator-Mediator Variable Distinction in Social Psychological Research: Conceptual, Strategic , and Statistical Considerations. Journal of Personality and Social Psychology, 51(6), 1173-1182.

Basheka, B. C. (2014). What constrains a transformed Public Service in Uganda. Journal of Public Administration, $49(2.1), 653-671$.

Bass, B. M. \& Avolio, B. J. (2000). MLQ Multifactor Leadership Questionnaire. Redwood City, CA: Mind Garden.

Bass, B. M. (1990). Bass and Stogdill's handbook of leadership: Theory, research and managerial applications ( $3^{\text {rd }}$ ed.). New York: Free Press.

Bass, B. M. (1985). Leadership and performance beyond expectations. New York: Free Press.

Biswas, S., \& Varma, A. (2011). Antecedents of employee performance: an empirical investigation in India. Employee Relations, 34(2), 177-192. https://doi.org/10.1108/01425451211191887

Blau, P. M. (1964). Exchange and power in social life. New York: John Wiley.

Breevaart, K., Bakker, A. B., Demerouti, E., Heuvel, M. Van Den, Breevaart, K., \& Bakker, A. B. (2015). Leadermember exchange, work engagement, and job performance. https://doi.org/10.1108/JMP-03-2013-0088

Bui, H. T. M., Zeng, Y., \& Higgs, M. (2017). The role of person-job fit in the relationship between transformational leadership and job engagement. Journal of Managerial Psychology, 32(5), 373-386. https://doi.org/10.1108/JMP-05-2016-0144

Choon, H., Ibrahim, R., Kowang, T. O., \& Fei, G. C. (2018). Employee Engagement as a Mediator Between Transformational Leadership and Employee Performance. Asian Journal of Scientific Research, 11, 441-448. https://doi.org/10.3923/ajsr.2018.441.448

Chugtai, A. A., \& Buckley, F. (2011). Work engagement: antecedents, the mediating role of learning goal 
orientation and job performance. Career Development International, 16(7), 684-705. https://doi.org/10.1108/13620431111187290

Conger, J. A. \& Kanungo, R. N. (1987). Toward a behavioral theory of charismatic leadership in organizational settings. The Academy of Management Review, 12(4), 637-647.

Datche, E. A., \& Mukulu, E. (2015). The effects of transformational leadership on employee engagement: A survey $\backslash$ of civil service in Kenya. Issues in Business Management and Economics, 3(1), 9-16.

Datche, E., \& Gachunga, H. (2015). Effects of Transformational leadership on Employee Engagement: The mediating role of Employee Engagement. International Journal of Management, 6(2), 1-8.

Du, H., Xie, B., \& Mo, L. (2017). Work engagement and job performance: The moderating role of perceived organizational support. Anales de Psicologia, 33(3), 708-713. https://doi.org/10.6018/analesps.33.3.238571

Etikan, I., Musa, S. A., \& Alkassim, R. S. (2016). Comparison of convenience sampling and purposive sampling. American Journal of Theoretical and Applied Statistics, 5(1), 1-4. https://doi.org/10.11648/j.ajtas.20160501.11

George, J.M., \& Jones,G.R. (2012).Understanding and managing Organizational Behavior. New Jersey, NJ: Prentice Hall

Geyer, A. L. J. \& Steyrer, J. M. (1998). Transformational leadership and objective performance in banks. Applied Psychology: An International Review, 47, 397-420.

Ghadi, M. Y., Fernando, M., \& Caputi, P. (2013). Transformational leadership and work engagement: The mediating effect of meaning in work. Leadership \& Organization Development Journal, 34(6), 532-550. https://doi.org/10.1108/LODJ-10-2011-0110

Gyensare, M. A., Kumedzro, L. E., Sanda, M.-A., \& Boso, N. (2017). Linking transformational leadership to turnover intention in the public sector: The influences of engagement, affective commitment and psychological climate. African Journal of Economic and Management Studies, 8(3), 314-337.

Hamman, D. (2012). Transformational Leadership and Employee Engagement amongst Knowledge Workers. University of Pretoria.

Homans, C. (1958). Social Behaviour as Exchange. American Journal of Sociology, 63(6), 597-606.

Jackson, L. (2014). The Work Engagement and Job Performance Relationship : Exploring the Mediating Effect of Trait Emotional Intelligence. San Jose State University.

Kahn, W. A. (1990). Psychological conditions of personal engagement and disengagement at work. Academy of Management Journal, 33(4), 692-724.

Karakas, F. (2010). Spirituality and performance in organizations: A literature review. Journal of Business Ethics, 94(1), 89-106.

Kikooma, J., Nansubuga, F., \& Research Team. (2017). HR analytics: Using people data to create value. Employer of the Year Awards 2017 main report.

Koopmans, L., Bernaads, C. M., Hildebrandt, V. H., Buuren, S. Van, Beek, A. J. Van Der, \& Vet, H. C. W. De. (2014). Improving the Individual Work Performance Questionnaire using Rasch Analysis. Journal of Applied Management, 15(2), 160-175.

Krejcie, R. V, \& Morgan, D. W. (1970). Determining Sample size for Research Activities. Educational and Psychological Measurement, 30, 607-610.

Lacap, J. P. G. (2019). The Mediating effect of employee engagement on the relationship of transformational leadership and intention to quit : Evidence from local colleges in Pampanga, Phillipines. Asia-Pacific Social Science Review, 19(1), 33-48.

Larsson, M., \& Lundholm, S. (2010). Leadership as work-embedded influence: a micro-discursive analysis of an everyday interaction in a bank. Leadership, 6(2), 159-184.

Lee, O. F., Tan, J. A., \& Javalgi, R. (2010). Goal orientation and organizational commitment Individual difference predictors of job performance. International Journal of Organizational Analysis, 18(1), 129-150. https://doi.org/10.1108/19348831011033249

Leung, M., Chan, Y. S. I., \& Dongyu, C. (2011). Structural linear relationships between job stress, burnout, physiological stress, and performance of construction project managers. Engineering, Construction and Architectural Management, 18(3), 312-328. https://doi.org/10.1108/09699981111126205

Lisbona, A., Palaci, F., Salanova, M., \& Frese, M. (2018). The effects of work engagement and self-ef fi cacy on personal initiative and performance. Psicothema, 30(1), 89-96. https://doi.org/10.7334/psicothema2016.245

Manzoor, F., Wei, L., Nurunnabi, M., Subhan, Q. A., Shah, S. I. A., \& Fallatah, S. (2019). The Impact of transformational leadership on job performance and CSR as a mediator in SMEs. Sustainability, 11(436), 114. https://doi.org/10.3390/su11020436

Memon, S. B., Soomro, S. B., \& Kumar, S. (2018). Assessing the work engagement, work practices and work performance in banks. Journal of Administrative and Business Studies, 4(3), 165-184. https://doi.org/10.20474/jabs-4.3.5

Ming, L. S. (2015). The Moderating effect of Reward in the relationship between Work Engagement and Job Performance. Universiti Tunku Abdul Rahman. 
Ministry of Public Service, (2011). Establishment notice No.1. Retrieved from: https://psc.go.ug/sites/default/files/downloads/EstablishmentNoticeNo.12011.pdf

Nazarian, A., Soares, A., \& Lottermoser, B. (2017). Inherited organizational performance? The perceptions of generation Y on the influence of leadership styles. Leadership \& Organization Development Journal, 38(8), 1078-1094. https://doi.org/10.1108/LODJ-05-2016-0119

Nunnally, J. C. (1978). Psychometric theory (2 ${ }^{\text {nd }}$ ed.). New York, NY: McGraw-Hill.

OECD, (2001). Public sector leadership for the $21^{\text {st }}$ Century. Retrieved from: www.oecd.org/governance/pem/2434104.pdf.

Para-gonzález, L., Jiménez-jiménez, D., \& Martínez-lorente, A. R. (2018). Exploring the mediating effects between transformational leadership and organizational performance. Employee Relations, 40(2), $423-426$.

Pham-thai, N. T., McMurray, A. J., Muenjohn, N., \& Muchiri, M. (2018). Job engagement in higher education. Personnel Review, 47(4), 951-967. https://doi.org/10.1108/PR-07-2017-0221

Pradhan, R. K., \& Jena, L. K. (2017). Employee Performance at Workplace : Conceptual model and empirical validation. Business Perspectives and Research, 5(1), 1-17. https://doi.org/10.1177/2278533716671630

Pradhan, S., Jena, L. K., \& Bhattacharyya, P. (2018). Transformational leadership and contextual performance: Role of integrity among Indian IT professionals. International Journal of Productivity and Performance Management, 67(2), 455-456.

Raja, M. W. (2012). Does Transformational Leadership Lead To Higher Employee Work Engagement. A Study of Pakistani Service Sector Firms. International Journal of Academic Research in Business and Social Sciences, 2(1), 160-166.

Reina-tamayo, A. M., Bakker, A. B., \& Derks, D. (2018). The work engagement - performance link: an episodic perspective. Career Development International, 23(5), 478-496. https://doi.org/10.1108/CDI-10-2017-0179

Ribeiro, N., Yucel, I., \& Gomes, D. (2018). How transformational leadership predicts employees ' affective commitment and performance. International Journal of Productivity and Performance Management, 67(9), 1909-1910. https://doi.org/10.1108/IJPPM-09-2017-0229

Robertson, I. T., Birch, A. J., \& Cooper, C. L. (2012). Job and work attitudes, engagement and employee performance: Where does psychological well-being fit in ? Leadership \& Organization Development Journal, 33(3), 224-232. https://doi.org/10.1108/01437731211216443

Salanova, M., Lorente, L., Chambel, M. J., \& Martınez, I. M. (2011). Linking transformational leadership to nurses' extra-role performance: the mediating role of self-efficacy and work engagement. Journal of Advanced Nursing, 67(10), 2256-2266. https://doi.org/10.1111/j.1365-2648.2011.05652.x

Sandell, K. (2012). Transformational Leadership, Engagement and Performance: A New Perspective. Master's Thesis. Colorado State University.

Sendawula, K., Kimuli, S. N., Bananuka, J., \& Muganga, G. N. (2018). Training, employee engagement and employee performance : Evidence from Uganda's health sector. Cogent Business \& Management, 5(1), 1-12. https://doi.org/10.1080/23311975.2018.1470891

Sanneh, L. (2015). Employee engagement in the public sector: a case study of Western Africa. International Journal of Human Resource Studies, 5(3), 70-101.

Schaufeli, W. (2013). What is engagement? London: Routledge.

Schaufeli, W. B., Salanova, M., Gonzalez-Romá, V., \& Bakker, A. B. (2002). The measurement of engagement and burnout: A two sample confirmatory factor analytic approach. Journal of Happiness Studies, 3, 71-92.

Schein, E. H. (2010). Organizational Culture and Leadership. San Francisco: Jossey-Bass.

Shokory, S. M., \& Suradi, N. R. M. (2018). Transformational leadership and its impact on extra-role performance of project team members: The mediating role of work engagement. Academy of Strategic Management Journal, 17(5), 1-6.

Soares, C., Veloso, A., Ferreira-Oliveira, A. T., \& Silva, I. (2017). Work engagement and performance: daily fluctuations. Study of the Organisation and Human Resource Quartely, 2(2), 18-27.

Thisera, T. J. R., \& Sewwandi, E. P. I. (2018). Transformational leadership and employee engagement in the hospitality sector in Sri Lanka. Global Journal of Management and Business Research: $(A), 18(12)$.

Ubaid, R. U., Rehman, C. A., Kashif, I. M., \& Aslam, U. (2017). Does team orientation matter? Linking work engagement and relational psychological contract with performance. Management Development, 36(9), 1102-1113. https://doi.org/10.1108/JMD-10-2016-0204

Vajda, P.G., SpiritHeart. (2008), The thrill is gone - When employees disengage. Available from: $\mathrm{http}: / /$ www.spiritheart.net/media/the thrill_is_gonewhen_employees_disengage.pdf.

Wright, T. A., \& Cropanzano, R. (2000). Psychological Well-Being and Job Satisfaction as Predictors of Job Performance. Journal of Occupational Health Psychology, 5(1), 84-94. https://doi.org/10.1037//10768998.5.1.84

Xu, J., \& Cooper-Thomas, H. D. (2011). How Can Leaders Achieve High Employee Engagement? 